\title{
The Efficiency of China's Retail Companies and the Implications in the Stock Market
}

\author{
Haolin Feng ${ }^{1}$, Xia Pan $^{1}$, Yanli Tang ${ }^{1} \&$ Liujie Xu ${ }^{2}$ \\ ${ }^{1}$ Lingnan College, Sun Yat-sen University, Guangzhou, China \\ ${ }^{2}$ Guangzhou Iron \& Steel Enterpricse Holdings Limited, Guangzhou, China \\ Correspondence: Haolin Feng, Lingnan College, Sun Yat-sen University, Guangzhou, 510275, China. E-mail: \\ fenghaol@mail.sysu.edu.cn
}

Received: February 7, 2015

Accepted: March 3, 2015

Online Published: March 14, 2015

doi:10.5539/ibr.v8n4p83

URL: http://dx.doi.org/10.5539/ibr.v8n4p83

\begin{abstract}
China's retail industry flourishes as its economy continues to grow rapidly. However, traditional Chinese retail firms are facing tremendous pressure, both from their international competitors operating in China and from the rise of the e-commerce industry. We study the efficiency of the Chinese retail firms in the domestic retail market. Specifically, we study seventeen publicly traded firms in China's Retail Industry by taking a Data Envelopment Analysis (DEA) approach. Besides investigating the areas for improvement in efficiency, we also compare the performance of the firms against their performance in the stock market. We then present the discussions of the implications for investors in the stock market. One of our main contributions is that, we relate the performance in stock market with the DEA analysis, which sheds some light on the effectiveness of the DEA method.
\end{abstract}

Keywords: China's retail industry, efficiency, data envelopment analysis, DEA

\section{Introduction}

The prominent growth of China's economy leads to the tremendous expansion of the retail industry of the country in the last few decades. China now has the world's second largest retail market next to the United States, according to the Ministry of Commerce of China. At the same time, the traditional Chinese retail firms are facing tremendous competition pressure both from their foreign competitors operating in China and from the rise of the e-commerce industry. While foreign retailers outperform domestic players in terms of both operating efficiency and gross profit margins, the more and more popular online shopping will soon take about $10 \%$ the country's total retail sales (Fung Business Intelligence Centre, 2013). In such context, the importance of improving efficiency for the traditional Chinese retailers is self-evident. A natural question arises: could some of the input (resources) be reduce to yield the same output?

It is well known that having suitable measures for business performance is essential for modern management. Developing effective performance metrics is always an important task in management studies. Data envelopment analysis (DEA) is one of the useful performance evaluation/ranking methods, among others (such as, analytical hierarchy process, balanced scorecard, etc.) that can be used for this purpose. A prominent feature of DEA is its mathematical rigor and methodological objectiveness, since the weights for each of the factors are not given a prior. There are also studies in DEA that empirically support the association between the causes (inputs) and results (outputs) (see, for example, Keh \& Chu, 2003). However, much less has been done in justifying the effectiveness and usefulness of DEA from the point of view of marketplace such as stock market in which performance of stocks are somewhat linked to the companies' business performance. This suggests that a third party indication to verify the DEA's effectiveness is needed.

In this paper, we use DEA to analyze the efficiency of the Chinese retail firms whose stocks are publicly traded either at Shanghai Stock Exchange or Shenzhen Stock Exchange. Through the analysis, we identify the potential improvement areas for the inefficient retailers. Besides the efficiency benchmarking, we attempt to study the next question: does those firms' performance in the stock market reflect their performance in terms of operating efficiency computed by DEA?

Here is the outline of the rest of the paper. We briefly review the related literature in section 2, and section 3 provides a brief introduction to the method of DEA as well as the data collection and model specification for the 
study of the retail firms' efficiency. We present the analysis of the efficiency as well as the discussion on the performance at the stock market in section 4 , while concluding remarks are provided in section 5 .

\section{Literature Review}

The efficiency issue of retailers, in general, has received much attention in literature, e.g., Achabal et al. (1984), Thomas et al. (1998), Keh and Chu (2003). The marketers are interested in efficiency/productivity for several reasons, such as lowering costs/increasing margins, being able to be low-price leader, being able to invest in new technologies and research, among others (Keh \& Chu). Academic researchers are divided as to how to define and measure productivity in retail industry, and different measures are used in literature (Donthu \& Yoo, 1998; Keh, 2000). Efficiency refers to the relationship between inputs and outputs, and there are multiple inputs and outputs in retail industry, making it complicated to clearly define the efficiency as the ratio of outputs to input. A popular approach to handle the multi-input/output problems is the Data Envelopment Analysis (DEA).

DEA was first introduced by Charnes, Cooper and Rhodes in 1978 to evaluate the efficiency of decision making units (DMUs) where multiple inputs/outputs are involved, and their original model is commonly referred to as the CCR model. Banker et al. (1984) further developed the DEA method and introduced a new model--the BCC model. Since the birth of DEA, a lot has been done in studying the theory of DEA, and we refer the interested readers to Cook \& Seiford (2009) which is a comprehensive review of the DEA theory in the past three decades. Thousands of applications of DEA could be found in literature, be the DMUs schools (Grosskopf et al., 1999), hospitals (Hofmarcher et al., 2002), banks (Khankhoje \& Sathye, 2008; Ar \& Kurtaran, 2013; Ayadi, 2014), hotels (Hu et al., 2014), local government entities (Fan et al., 2013), and supply chains (Salhieh, 2011), just to name a few. Recently, Anadol et al. (2014) applied the tool of DEA to the problem of valuing private companies, which is an innovative application of the DEA method. Besides the above, DEA has also been applied to study the efficiency in the high-tech industry (Feng et al., 2013).

Regarding the efficiency in the retail industry, which is the focus of this paper, DEA has also been applied in literature. Keh and Chu (2003) took a DEA approach to study the firm level's scale of economies in the retail industry. Fu et al. (2012) used British retail sales data to study how the foreign capital affects the management and performance of British enterprise. Mohamed (2010) applied DEA to study the relationship between the efficiency and the profits, using the data of the 45 retail companies among the US Fortune 500 companies.

This paper focuses on assessing the efficiency of the domestic retail companies in China in recent years. DEA is used to analyze the efficiency and to identify the main areas for improvement. We also compare the efficiency of the firms against their performance in the stock market to investigate the relationship between the operating efficiency and the Price-Earnings ratio. In this way, we contribute to the literature by not only studying the retail firms' efficiency, but also its implications to stock market investors.

\section{The DEA Methodology}

\subsection{A Brief Introduction to the DEA Methodology}

DEA is a technique for evaluating the relative performance of a set of operating entities (the decision making units, or DMUs) by considering multiple inputs and outputs simultaneously. In DEA, the efficiency $E$ of a DMU, namely DMU $i_{0}$, is obtained by maximizing the ratio of weighted outputs to weighted inputs, subject to the constraint that the same weight vectors applying to any DMU's inputs and outputs could not result in a ratio greater than $100 \%$ (since each DMU could only be $100 \%$ efficient at best).

Formally, the CCR model developed by Charnes et al. (1978) is the following mathematical program:

$$
\begin{aligned}
& \operatorname{Max} E=\frac{u^{T} y_{i 0}}{v^{T} x_{i 0}} \\
& \left\{\begin{array}{l}
\frac{u^{T} y_{i}}{v^{T} x_{i}} \leq 1, \quad i=1,2,3, \ldots \mathrm{I} \\
u \geq 0, v \geq 0, u^{T} \neq 0, v^{T} \neq 0
\end{array}\right.
\end{aligned}
$$

Here $x_{i}=\left[x_{i, 1}, x_{i, 2}, x_{i, 3}, \ldots, x_{i, M}\right]$, and $y_{i}=\left[y_{i, 1}, y_{i, 2}, y_{i, 3}, \ldots, y_{i, N}\right]$ represent the input and output data, respectively, for DMU $i$, assuming there are M types of input and $\mathrm{N}$ types of output for each of the DMUs. And $\mathrm{u}=\left[u_{1}, u_{2}, \ldots, u_{M}\right]$ and $\mathrm{v}=\left[v_{1}, v_{2}, \ldots, v_{N}\right]$ are the weight vectors for the outputs and inputs, respectively.

Applying the Charnes-Cooper transformation and the duality theory, the CCR model becomes a linear program: 


$$
(C C R)\left\{\begin{array}{c}
\min \left[\theta-\varepsilon\left(e_{1}^{T} S^{-}+e_{2}^{T} S^{+}\right)\right] \\
\text {s.t. } \sum_{i=1}^{I} \lambda_{i} x_{i}+S^{+}=\theta x_{i 0} \\
\sum_{i=1}^{I} \lambda_{i} y_{i}-S^{-}=y_{i 0} \\
\lambda_{i} \geq 0, i=1, \ldots, I \\
S^{-}, S^{+} \geq 0
\end{array}\right.
$$

Here $\varepsilon$ is the Non-Archimedean infinitesimal; $\mathrm{e}_{1}=\mathrm{e}_{2}=(1,1, \ldots, 1)^{T} ; S^{+}$and $S^{-}$are the slack variables for the input and output, respectively. And $\lambda=\left[\lambda_{1}, \lambda_{2}, \ldots, \lambda_{I}\right]$ is the weight vector to "synthesize a virtual DMU" using the set of original DMUs. Intuitively, if one could "construct" a new DMU such that it generates at least as much output as the DMU $i_{0}$ does but only a portion $\theta(<1)$ of the input of DMU $i_{0}$ is required, then it implies that DMU $i_{0}$ is less efficient, comparing to the DMU "constructed". That is what the linear program above trying to do: to use a linear combination of the original DMUs to construct a "virtual" DMU to minimize $\theta$ (the portion of input needed) while generating no less output than DMU $i_{0}$ does. On the other hand, if at an optimum of the linear program above, $\theta^{*}=1$ and $S^{+*}=S^{-*}=0$ (in the element-wise sense), then, one could not beat the performance of DMU $i_{0}$ by using the combination of the original DMUs. In this case, DMU $i_{0}$ has the efficiency $\theta^{*}=100 \%$, and thus it is efficient (Banker et al., 1984). The model above is sometimes called input-oriented, since it tries to minimize the input resources. To evaluate the efficiency of each of the DMUs, one could repeat the above process by enumerating $i_{0}$ from 1 to $I$.

Note that the CCR model above implicitly assumes constant returns to scale, and one could allow variable returns to scale by adding an extra constraint that $\sum_{i} \lambda_{i}=1$, which requires the weights sum to one. The result of this modification is the BCC model (Banker et al. 1984):

$$
(B C C)\left\{\begin{array}{c}
\min \left[\theta-\varepsilon\left(e_{1}^{T} S^{-}+e_{2}^{T} S^{+}\right)\right] \\
\text {s.t. } \sum_{i=1}^{I} \lambda_{i} x_{i}+S^{+}=\theta x_{i 0} \\
\sum_{i=1}^{I} \lambda_{i} y_{i}-S^{-}=y_{i 0} \\
\sum_{i=1}^{I} \lambda_{i}=1 \\
\lambda_{i} \geq 0, i=1, \ldots, I \\
S^{-}, S^{+} \geq 0
\end{array}\right.
$$

The BCC model is the one we are going to use in our analysis since it allows variable returns to scale.

\subsection{Data Collection and Model Specification}

We focus on the companies listed in the Shanghai Stock Exchange and Shenzhen Stock Exchange. We look at the companies whose major business is retailing and those who were listed in either Exchange no later than 2010. There are seventeen companies meeting such criteria, all of which are major domestic retailers in China. (The reason why we decide to choose screen out the companies listed later 2010 is that, our later analysis needs several years' data to investigate the relationship between the retail efficiency and the performance in the stock market.) These seventeen companies are the DMUs for our study, and their information can be found in Table 1. (We use the companies' code name/code number listed in the Exchange. The full name of the companies can be found in Appendix A.) 
Table 1. The information of the 17 DMUs

\begin{tabular}{cccccc}
\hline DMU id\# & Company Code Name(code \#) & DMU id\# & Company Code Name(code \#) & DMU id\# & Company Code Name(code \#) \\
\hline 1 & NJCE(600280) & 7 & LZMB(600738) & 13 & XAMS $(000564)$ \\
2 & SHNW(600628) & 8 & YCXH(600785) & 14 & ZBHG(000759) \\
3 & NJXJ(600682) & 9 & BJWF(600859) & 15 & GZGB(002187) \\
4 & FJDB(600693) & 10 & HBCR $(600891)$ & 16 & RBDS(002419) \\
5 & NNDS(600712) & 11 & YHSS $(601933)$ & 17 & SHJB $(600838)$ \\
6 & CQDS(600729) & 12 & HFDS $(000417)$ & & \\
\hline
\end{tabular}

Next, we need to determine the input and output for the DMUs. On the financial statements of the listed companies, there are many types of income and expenditure related items. In this work, since we want to explore how the expenses of operation, sales and management affect the operational efficiency and the profits, we decide that the five items on the financial statements are most relevant to our study: the operating costs, the selling expenses, the administrative expenses, the return on total assets, and operating profit ratio. Note that different countries have slightly difference accounting practices, and we will provide explanations of some of these terms whenever necessary. Since the costs and expenses are under DMUs' managerial control, they are the input variables in our DEA model. On the other hand, the returns on assets and the operating profit ratio are the results of the retail business, and thus they are the output variables in the model.

The data for the aforementioned variables are available in the database CSMAR Solution which is a comprehensive database for Chinese business research. CSMAR covers data on the Chinese stock market, financial statements and China corporate governance of listed firms in China. Table 2 provides an outlook of the data for inputs and outputs for each year (Note 1). The data for the fiscal year 2014 is not available yet, and we confine ourselves to use the data no earlier than 2010, since earlier data is not available for some of the companies who were not listed in either Exchange until 2010.

Table 2. Sample data of the inputs and outputs

\begin{tabular}{|c|c|c|c|c|c|c|}
\hline \multirow{2}{*}{ Company } & \multirow{2}{*}{ Year } & \multicolumn{3}{|c|}{ Inputs (Unit: RMB) } & \multicolumn{2}{|c|}{ Outputs (Unit: RMB) } \\
\hline & & Operating Costs & Selling Expenses & Administrative Expenses & Return on Total Assets (\%) & Operating Profit Ratio (\%) \\
\hline \multirow{4}{*}{$\begin{array}{c}\text { NJCE } \\
(600280)\end{array}$} & 2010 & 3898554624.87 & 236400785.52 & 497963296.07 & 2.2548 & 2.3949 \\
\hline & 2011 & 5194403762.04 & 289067668.51 & 545259230.52 & 2.8555 & 4.0958 \\
\hline & 2012 & 4675394688.55 & 290734890.91 & 595980915.73 & 3.2222 & 1.8066 \\
\hline & 2013 & 5451947937.25 & 322369899.92 & 440757751.06 & 7.4951 & 10.7445 \\
\hline
\end{tabular}

Here is how Return on Total Assets and the Operating Profit Ratio are computed. One could also find them directly from the CSMAR database.

Return on Total Assets $=($ Total profit + Financial expenses $) /$ Average total assets $\times 100 \%$

Average total assets $=($ The closing balance of total assets + The opening balance of total assets $) / 2$

Operating Profit Ratio = Operating Profit/Operating Revenue $\times 100 \%$.

Now that the input and output data of the DEA (BCC model) has been specified, computing the efficiency of the companies for each year is just to solve a bunch of linear programs. We will discuss the result and the analysis in next section.

\section{Analysis}

\subsection{Analysis at the Firm Level}

Using the model and data described in section 3, we compute the efficiencies for the companies on an annual basis. The results can be found in Table 3. (Each year, the companies are sorted according to their efficiencies.) From the sorted results, we can see that the ranking is largely stable over years, although there are slight differences from one year to another. In particular, SHJB and HBCR are the performance leaders in all four years 
while ZBHG is always among the least efficient ones. Later in subsection 4.3, we will discuss the relationship between the performance evaluation obtained by our DEA model and that evaluated by the stock market.

Table 3. The efficiencies obtained by the DEA

\begin{tabular}{|c|c|c|c|c|c|c|c|}
\hline Company & $\begin{array}{c}\text { Efficiency } \\
(2010)\end{array}$ & Company & $\begin{array}{c}\text { Efficiency } \\
(2011)\end{array}$ & Company & $\begin{array}{c}\text { Efficiency } \\
\text { (2012) }\end{array}$ & Company & $\begin{array}{c}\text { Efficiency } \\
(2013)\end{array}$ \\
\hline $\begin{array}{c}\text { SHJB } \\
(600838)\end{array}$ & 1.00 & $\begin{array}{c}\text { SHJB } \\
(600838)\end{array}$ & 1.00 & $\begin{array}{c}\text { SHJB } \\
(600838)\end{array}$ & 1.00 & $\begin{array}{c}\text { SHJB } \\
(600838)\end{array}$ & 1.00 \\
\hline $\begin{array}{c}\text { HBCR } \\
(600891)\end{array}$ & 1.00 & $\begin{array}{c}\text { HBCR } \\
(600891)\end{array}$ & 1.00 & $\begin{array}{c}\text { HBCR } \\
(600891)\end{array}$ & 1.00 & $\begin{array}{c}\text { HBCR } \\
(600891)\end{array}$ & 1.00 \\
\hline $\begin{array}{c}\text { FJDB } \\
(600693)\end{array}$ & 1.00 & $\begin{array}{c}\text { FJDB } \\
(600693)\end{array}$ & 1.00 & $\begin{array}{c}\text { NJXJ } \\
(600682)\end{array}$ & 1.00 & $\begin{array}{c}\text { FJDB } \\
(600693)\end{array}$ & 1.00 \\
\hline $\begin{array}{c}\text { LZMB } \\
(600738)\end{array}$ & 0.69 & $\begin{array}{c}\text { LZMB } \\
(600738)\end{array}$ & 0.64 & $\begin{array}{c}\text { LZMB } \\
(600738)\end{array}$ & 1.00 & $\begin{array}{c}\text { LZMB } \\
(600738)\end{array}$ & 1.00 \\
\hline $\begin{array}{c}\text { NJXJ } \\
(600682)\end{array}$ & 0.33 & $\begin{array}{c}\text { YCXH } \\
(600785)\end{array}$ & 0.41 & $\begin{array}{c}\text { YCXH } \\
(600785)\end{array}$ & 1.00 & $\begin{array}{c}\text { NJCE } \\
(600280)\end{array}$ & 1.00 \\
\hline $\begin{array}{c}\text { YCXH } \\
(600785)\end{array}$ & 0.32 & $\begin{array}{c}\text { GZGB } \\
(002187)\end{array}$ & 0.34 & $\begin{array}{c}\text { FJDB } \\
(600693)\end{array}$ & 0.916 & $\begin{array}{c}\text { GZGB } \\
(002187)\end{array}$ & 0.916 \\
\hline $\begin{array}{c}\text { GZGB } \\
(002187)\end{array}$ & 0.26 & $\begin{array}{c}\text { NJXJ } \\
(600682)\end{array}$ & 0.32 & $\begin{array}{c}\text { SHNW } \\
(600628)\end{array}$ & 0.881 & $\begin{array}{c}\text { YCXH } \\
(600785)\end{array}$ & 0.881 \\
\hline $\begin{array}{c}\text { NNDS } \\
(600712)\end{array}$ & 0.26 & $\begin{array}{c}\text { NNDS } \\
(600712)\end{array}$ & 0.29 & $\begin{array}{c}\text { HFDS } \\
(000417)\end{array}$ & 0.378 & $\begin{array}{c}\text { SHNW } \\
(600628)\end{array}$ & 0.378 \\
\hline $\begin{array}{c}\text { XAMS } \\
(000564)\end{array}$ & 0.21 & $\begin{array}{c}\text { RBDS } \\
(002419)\end{array}$ & 0.22 & $\begin{array}{c}\text { GZGB } \\
(002187)\end{array}$ & 0.365 & $\begin{array}{c}\text { CQDS } \\
(600729)\end{array}$ & 0.365 \\
\hline $\begin{array}{c}\text { RBDS } \\
(002419)\end{array}$ & 0.20 & $\begin{array}{c}\text { XAMS } \\
(000564)\end{array}$ & 0.19 & $\begin{array}{c}\text { RBDS } \\
(002419)\end{array}$ & 0.251 & $\begin{array}{c}\text { NNDS } \\
(600712)\end{array}$ & 0.251 \\
\hline $\begin{array}{c}\text { SHNW } \\
(600628)\end{array}$ & 0.15 & $\begin{array}{c}\text { SHNW } \\
(600628)\end{array}$ & 0.15 & $\begin{array}{c}\text { NNDS } \\
(600712)\end{array}$ & 0.234 & $\begin{array}{c}\text { NJXJ } \\
(600682)\end{array}$ & 0.234 \\
\hline $\begin{array}{c}\text { YHSS } \\
(601933)\end{array}$ & 0.12 & $\begin{array}{c}\text { HFDS } \\
(000417)\end{array}$ & 0.14 & $\begin{array}{c}\text { BJWF } \\
(600859)\end{array}$ & 0.144 & $\begin{array}{c}\text { RBDS } \\
(002419)\end{array}$ & 0.144 \\
\hline $\begin{array}{c}\text { HFDS } \\
(000417)\end{array}$ & 0.10 & $\begin{array}{c}\text { YHSS } \\
(601933)\end{array}$ & 0.12 & $\begin{array}{c}\text { XAMS } \\
(000564)\end{array}$ & 0.14 & $\begin{array}{c}\text { XAMS } \\
(000564)\end{array}$ & 0.14 \\
\hline $\begin{array}{c}\text { NJCE } \\
(600280)\end{array}$ & 0.09 & $\begin{array}{c}\text { BJWF } \\
(600859)\end{array}$ & 0.10 & $\begin{array}{c}\text { CQDS } \\
(600729)\end{array}$ & 0.132 & $\begin{array}{c}\text { HFDS } \\
(000417)\end{array}$ & 0.132 \\
\hline $\begin{array}{c}\text { BJWF } \\
(600859)\end{array}$ & 0.09 & $\begin{array}{c}\text { NJCE } \\
(600280)\end{array}$ & 0.09 & $\begin{array}{c}\text { YHSS } \\
(601933)\end{array}$ & 0.129 & $\begin{array}{c}\text { YHSS } \\
(601933)\end{array}$ & 0.129 \\
\hline $\begin{array}{c}\text { ZBHG } \\
(000759)\end{array}$ & 0.08 & $\begin{array}{c}\text { CQDS } \\
(600729)\end{array}$ & 0.09 & $\begin{array}{c}\text { NJCE } \\
(600280)\end{array}$ & 0.074 & $\begin{array}{c}\text { BJWF } \\
(600859)\end{array}$ & 0.074 \\
\hline $\begin{array}{c}\text { CQDS } \\
(600729)\end{array}$ & 0.07 & $\begin{array}{c}\text { ZBHG } \\
(000759)\end{array}$ & 0.09 & $\begin{array}{c}\text { ZBHG } \\
(000759)\end{array}$ & 0.067 & $\begin{array}{c}\text { ZBHG } \\
(000759)\end{array}$ & 0.067 \\
\hline
\end{tabular}

\subsection{Analysis at the Industry Level}

Aggregating the input and output of all the companies in our population, we compute the average input and output for each year from 2010 to 2013. The results could be found in Table 4. To better capture the trend over this four years period, we also presents the costs/expenses and the outputs in Figure 1 and Figure 2. 
Table 4. The average of the output factors and the input factors from 2010 to 2013

\begin{tabular}{cccccc}
\hline \multirow{2}{*}{ Year } & \multicolumn{3}{c}{ Inputs (Unit: RMB) } & \multicolumn{2}{c}{ Outputs (Unit: RMB) } \\
\cline { 2 - 6 } & Operating Costs & Selling Expenses & Administrative Expenses & Return On Total Assets (\%) & Operating Profit Ratio (\%) \\
\hline 2010 & 4923786235 & 573894481.2 & 245769354.9 & 8.27 & 5.78 \\
2011 & 6353562374 & 820013060.3 & 262792378 & 7.09 & 5.54 \\
2012 & 7078369249 & 955389121.2 & 324512548.3 & 5.10 & 5.57 \\
2013 & 7777978321 & 1099794682 & 346799435 & 4.96 & 5.54 \\
\hline
\end{tabular}

Figure 1(a)-(c) shows the trend of each of the average input variables at the industry level, while Figure 2 is that for the output variables. The trend is that all types of costs/expenses have increased significantly over the period 2010-2013, and the greatest increase is found in the item 'selling expenses' (almost doubled) while the item 'administrative expenses' is the one having the least increase over this 4 years period.

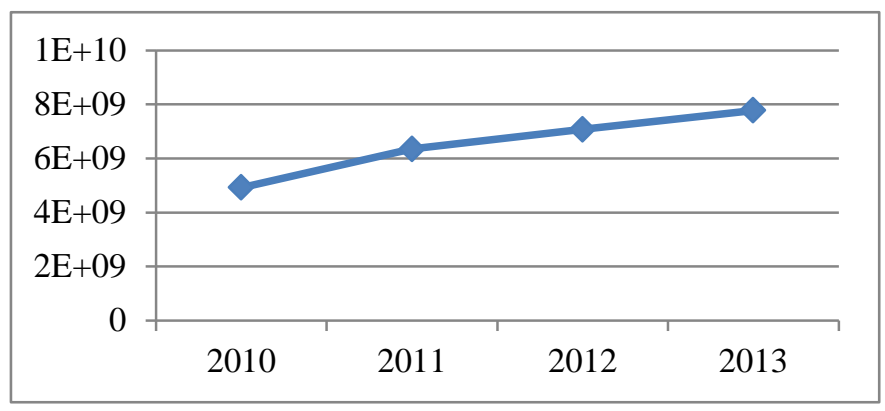

Figure 1(a). The average operating costs from 2010 to 2013

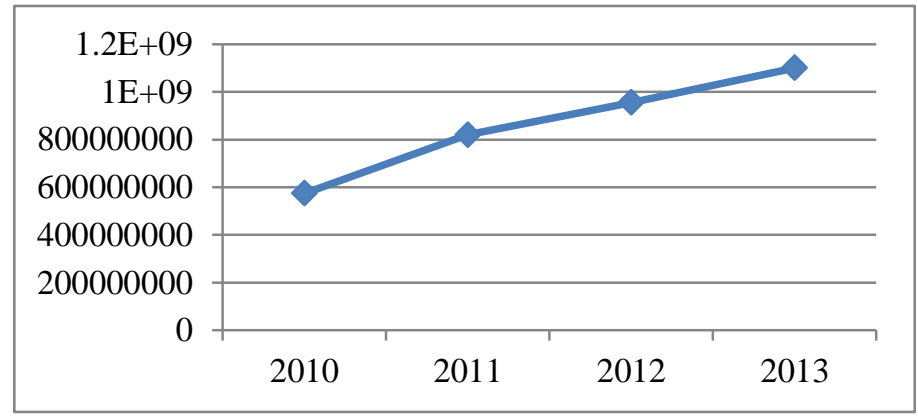

Figure 1(b). The average selling expenses from 2010 to 2013

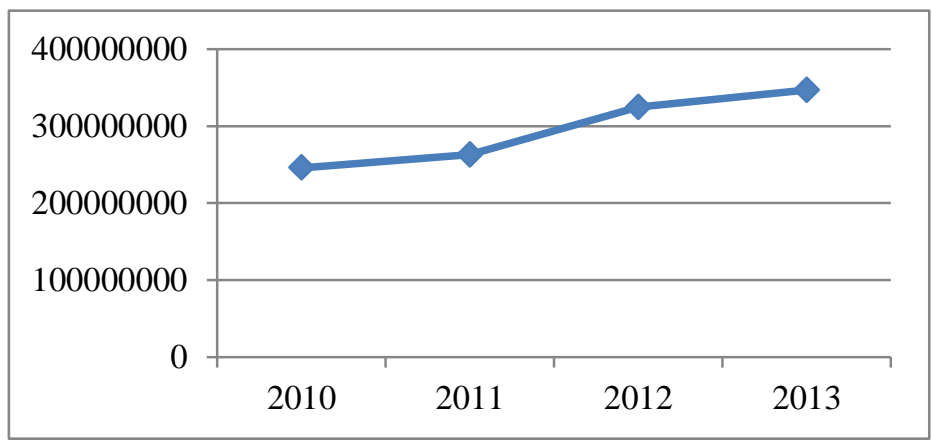

Figure 1(c). The average administrative expenses from 2010 to 2013 


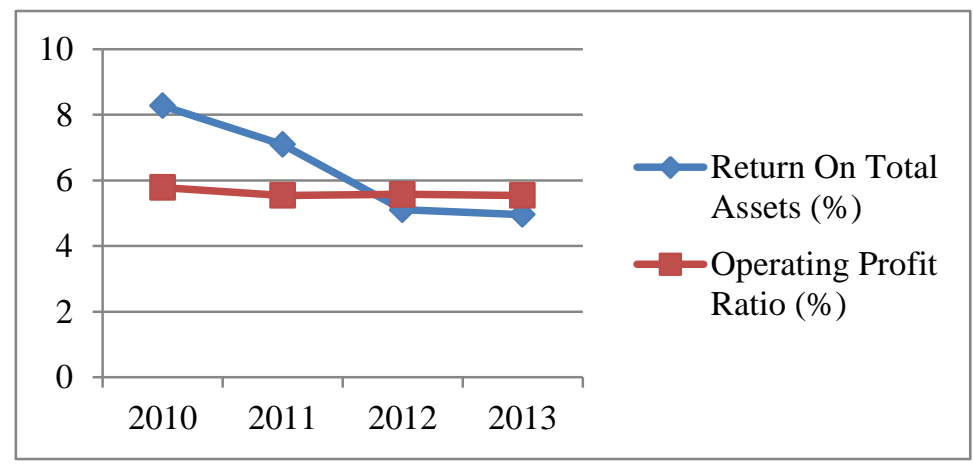

Figure 2. The average outputs from 2010 to 2013

On the other hand, at the industry level, the retail firms generally have suffered a significant decrease in the output, as one can see from Figure 2. While the 'Operating Profit Ratio' is relatively stable, the 'Return On Total Assets' is cut by about $40 \%$ over the 4 years period.

To sum up, these results show that, overall the retail industry is suffering from the decrease of efficiency, meaning that it takes more input resources to generate less output. Our intuitive explanation for this phenomenon is that, as the e-commerce continues to gain its popularity in China, the traditional offline retail business is losing its share to the e-commerce. And the significant increase of labor costs in recent year in China also contributes to the huge increase in the selling expenses.

The DEA model we used also offers another way to gain managerial insights about areas for improvement. In particular, when solving the BCC linear program described in section 3, the slack variables obtained can provide extra information. In the following, we are going to focus on the input resources since the BCC model we used is input oriented. Table 5 summarizes the average of the resulted slack values in the input resources.

Intuitively, the slack variables in the model indicate how much of the input resources a company could safe and yet could still keep the current efficiency by using the 'industry's best practice'. We can see that the item Selling Expenses has the largest room for improvement ( $9.5 \%)$, and the next one is the Operating Costs $(\sim 8 \%)$.

Table 5(a). The (average) slack values for the input resources from the BCC model

\begin{tabular}{ccc}
\hline $\begin{array}{c}\text { The average of the slack value for } \\
\text { Operating Costs }\end{array}$ & $\begin{array}{c}\text { The average of the slack value for Selling } \\
\text { Expenses }\end{array}$ & $\begin{array}{c}\text { The average of the slack value for } \\
\text { Administration Expenses }\end{array}$ \\
\hline 512910979 (RMB/firm/year) & $81409442(\mathrm{RMB} /$ firm/year) & 4122536 (RMB/firm/year) \\
\hline
\end{tabular}

Table 5(b). The (average) values for the input resources from the BCC model

\begin{tabular}{ccc}
\hline The average amount of Operating Costs & The average amount of Selling Expenses & The average amount of Administration Expenses \\
\hline 6533424045 (RMB/firm/year) & 862272836 (RMB/firm/year) & $294968429(\mathrm{RMB} / \mathrm{firm} / \mathrm{year})$ \\
\hline
\end{tabular}

Table 5(c). The (average) percentage of costs to improve values for the input resources from the BCC model

\begin{tabular}{ccc}
\hline $\begin{array}{c}\text { Percentage of costs to improve } \\
\text { (Operating Costs) }\end{array}$ & $\begin{array}{c}\text { Percentage of costs to improve (Selling } \\
\text { Expenses) }\end{array}$ & $\begin{array}{c}\text { Percentage of costs to improve } \\
\text { (Administration Expenses) }\end{array}$ \\
\hline $7.85 \%$ & $9.44 \%$ & $1.40 \%$ \\
\hline
\end{tabular}

\subsection{The Discussion about the DEA Efficiency and the Price/Earnings Ratio}

From the information about the annual ranking of the efficiency (Table 6), we can see that SHJB and HBCR are always performance leaders in all four years. On the other hand CQDS and ZBHG are the two companies with low efficiencies. Table 6 summarizes these four companies' efficiencies, while Table 7 and figure 3 provide the information of their Price/Earnings ratios (P/E) 
Table 6. The efficiency for the four companies

\begin{tabular}{ccccc}
\hline Company & 2010 & 2011 & 2012 & 2013 \\
\hline SHJB (600838) & 1 & 1 & 1 & 1 \\
HBCR (600891) & 1 & 1 & 1 & 1 \\
ZBHG (000759) & 0.08 & 0.09 & 0.067 & 0.075 \\
CQDS (600729) & 0.07 & 0.09 & 0.132 & 0.365 \\
\hline
\end{tabular}

Table 7. The P/E value

\begin{tabular}{ccccc}
\hline P/E & 2010 & 2011 & 2012 & 2013 \\
\hline SHJB (600838) & 119.7395 & 19.89514 & 80.5302 & 64.73648 \\
HBCR (600891) & 26.41635 & 96.71638 & 41.16788 & 54.14689 \\
CQDS (600729) & 30.97297 & 19.57538 & 13.62933 & 10.99879 \\
ZBHG (000759) & 34.06036 & 21.65734 & 22.25708 & 28.42231 \\
\hline
\end{tabular}

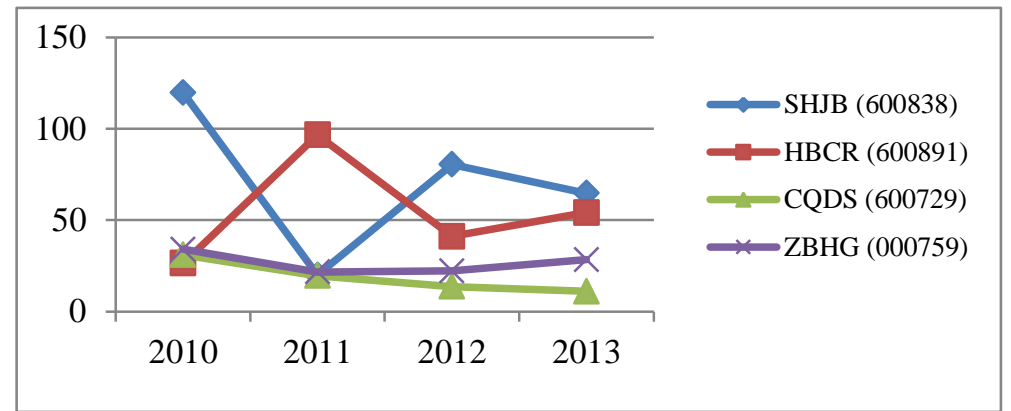

Figure 3. The P/E of SHJB, HBCR, CQDS and ZBHG from 2010 to 2013

From the sample data shown in Figure 3 and Table 6, one can see that the companies' operating performance evaluated by our DEA model is, in large part, consistent with the evaluation of the companies in stock market. Our interpretation about this observation is the following. First of all, the majority of investors, institutional or individual, in stock market make their investment decision more or less based on fundamental analysis, which relies significantly on the information provided in the financial statements of the companies. Those financial ratios are important indicators that the investors employ as reference in stock selection. On the other hand, what we have used as inputs and outputs in our DEA analysis is also part of the items and ratios from financial statements (such as costs, expenses, profit ratios and return ratios). In other words, the DEA ranking of efficiency is based on a subset of the information from the financial statements that is used by investors in stock market. Our results suggest that our DEA model may be able to capture the essential information from the financial statements to predict, in large part, the companies' business performance. This provides a justification of the DEA method wildly used in benchmarking/ranking DMUs' performance.

With further detailed examination of the results above, one can notice that (a) for companies whose DEA efficiencies are in different classes (e.g., SHJB vs. ZBHG or HBCR vs. CQDS), the companies with high DEA efficiency tend to also have higher P/E ratios than those in the low DEA efficiency group; (b) for the companies whose DEA efficiencies are in the same group, the DEA results could not explain the difference in their performance indicated by their P/E ratios. For example, SHJB and HBCR are both of very efficient in terms of the DEA evaluation, while ZBHG and CQDS are also both among those with lowest DEA efficiency, and little could be said about the P/E comparison in either case using the DEA ranking. Our explanation to observation (a) is that, with just a small subset of the financial information our DEA analysis is able to tell apart the companies with high business performance from the ones with low business performance, and the resulted evaluation of the companies are consistent with the investors in the stock market. Our argument for observation (b) is that, the DEA model we employed only utilizes a small subset of information from the financial statement, and companies with close DEA efficiency may actually differ in business performance in some aspects that our DEA model does not captured. The difference in those uncaptured aspects may result in different performance in stock 
market from time to time. Therefore, our study suggests that DEA analysis can partially match the performance in stock market in terms of P/E, which reflects how much the investors are willing to pay for each dollar of earnings per share of the stock.

\section{Contributions and Limitations}

In this paper, we developed a model utilizing the DEA method to analyze the efficiency of the domestic retailers in China. Our analysis shows that, the overall performance in this industry in China declined in the period from 2010 to 2013, since it tends to take more and more input resources to generate similar or even less output. Our results from the DEA also suggest that the item Selling Expenses is the one with the largest room for improvement among all the input resources considered, while the item Administration Expenses generally demands less improvement efforts. The inefficiency in the Selling Expenses may be due to overspending on marketing/advertisement and/or unnecessary promotion activities, and these aspects deserve the retailers' further discretion. We also investigate the relationship between the companies' DEA efficiency and their performance in the stock market indicated by the P/E ratios. We find that the efficiency evaluation obtained by our model is, in large part, consistent with that indicated by the P/E ratios: the (DEA) efficient companies tend to have higher P/E ratios than their (DEA) inefficient peers. On that other hand, for companies with similar DEA efficiencies, the DEA evaluation could not effectively predict their relative performance in the stock market measured by the P/E ratios. This is because, our DEA model takes only a subset of the information utilized by the investors in their investment decision, and thus we do not expected that it could perfectly match the companies' performance in the stock market. This result also suggests that, DEA may be useful for investors in their stock selection.

To sum up, our contributions are in two aspects: 1) our analysis of the efficiency of the domestic retail industry in China provides managerial insights about the industry; 2) we relate the performance in stock market with the DEA analysis, which sheds some light on the effectiveness of the DEA method. We believe that the latter aspect is an innovative contribution to the DEA research area.

The limitations of this work are the following. We just use four years data due to the fact that some of those retailers were not publicly traded until 2010. If we were to use the data with a longer period of time, some of the retailers in our population would have been excluded, which would make the population of our study too small. Also, the data we use are for the domestic retailers in China, and it will be interesting to see whether our findings still hold in other countries. This is a topic for further study.

\section{Acknowledgments}

This research is supported by National Natural Science Foundation of China (Grant No. 71172165 \& 71401187).

\section{References}

Achabal, D., Heineke, J., \& McIntyre, S. H. (1984). Issues and perspectives on retail productivity. Journal of Retailing, 60(3), 107-129. http://papers.ssrn.com/sol3/papers.cfm?abstract_id=1859566

Anadol, B., Joseph, P. C., Simak, P., \& Yang, X. (2014). Valuing private companies: A DEA approach. International Journal of Business and Management, 9(12), 16-27. http://dx.doi.org/10.5539/ijbm.v9n12p16

Ar, I. M., \& Kurtaran, A. (2013). Evaluating the relative efficiency of commercial banks in Turkey: An integrated AHP/DEA approach. International Business Research, 6(4), 129-146. http://dx.doi.org/10.5539/ibr.v6n4p129

Ayadi, I. (2014). Technical efficiency of Tunisian banks. International Business Research, 7(4), 170-182. http://dx.doi.org/10.5539/ibr.v7n4p170

Banker, R. D., Charnes, A., \& Cooper, W. W. (1984). Some models for estimating technical and scale efficiency in data envelopment analysis. Management Science, 30(9), 1078-1092. http://dx.doi.org/10.1287/mnsc.30.9.1078

Charnes, A., \& Cooper, W. W. (1962). Programming with linear fractional functionals. Naval Research Logistics Quarterly, 9, 67-88. http://dx.doi.org/10.1002/nav.3800090303

Charnes, A., Cooper, W. W., \& Rhodes, E. L. (1978). Measuring the efficiency of decision making units. European Journal of Operational Research, 2(6), 429-444. http://dx.doi.org/10.1016/0377-2217(78)90138-8

Cook, W. D., \& Seiford, L. M. (2009). Data envelopment analysis (DEA)-Thirty years on. European Journal of Operational Research, 192(1), 1-17. http://dx.doi.org/10.1016/j.ejor.2008.01.032

Donthu, N., \& Yoo, B. (1998). Retail productivity assessment using data envelopment analysis. Journal of 
Retailing, 74(1), 89-105. http://dx.doi.org/10.1016/S0022-4359(99)80089-X

Fan, Y., Yuan, X., \& Qin, J. (2013). Research on China's regional cultural industries' efficiency based on factor analysis and BCC \& super efficiency model. International Business Research, 6(7), 22-31. http://dx.doi.org/10.5539/ibr.v6n7p22

Feng, F., Wang, B., Zou, Y., \& Du, Y. (2013). A new internet DEA structure: Measurement of Chinese R\&D innovation efficiency in high technology industry. International Journal of Business and Management, 8(21), 32-40. http://dx.doi.org/10.5539/ijbm.v8n21p32

Feng, F., Zhou, N., Zhang, L., Du, Y., \& Ma, L. (2013). Research on the performance evaluation and S\&T resources allocation of high-tech industry of China: Evidence based on three different economic regions. International Journal of Business and Management, 8(5), 13-23. http://dx.doi.org/10.5539/ijbm.v8n5p13

Fu, X., Helmers, C., \& Zhang, J. (2012). The two faces of foreign management capabilities: FDI and productive efficiency in the UK retail sector. International Business Review, 21, 71-88. http://dx.doi.org/10.1016/j.ibusrev.2010.12.002

Fung Business Intelligence Centre. (2013). Retail Market in China. September 2013 [Market Research Report] Retrieved from http://www.funggroup.com/eng/knowledge/research/china_dis_issue114.pdf

Grosskopf, S., Hayes, K. J., Taylor, L. L., \& Weber, W. L. (1999). Anticipating the consequences of school reform: a new use of DEA. Management Science, 45(4), 608-620. http://dx.doi.org/10.1287/mnsc.45.4.608

Hofmarcher, M. M., Paterson, I., \& Riedel, M. (2002). Measuring hospital efficiency in Austria-a DEA approach. Health Care Management Science, 5(1), 7-14. http://dx.doi.org/10.1023/A:1013292801100

Hu, J. L., Yeh, F. Y., \& Tsai, Y. C. (2014). Regional traffic \& medical services and cost efficiency of international tourist hotels in Taiwan. International Business Research, 7(10), 36-46. http://dx.doi.org/10.5539/ibr.v7n10p36

Keh, H. T. (2000). Measuring retailer performance: Towards an understanding of productivity. Journal of Targeting, Measurement and Analysis for Marketing, 9(2), 160-173. http://dx.doi.org/10.1057/palgrave.jt.5740012

Keh, H. T., \& Chu, S. (2003). Retail productivity and scale economies at the firm level: A DEA approach. Omega, 31(2), 75-82. http://dx.doi.org/10.1016/S0305-0483(02)00097-X

Khankhoje, D., \& Sathye, M. (2008). Efficiency of rural banks: The case of India. International Business Research, 1(2), 140-149. http://dx.doi.org/10.5539/ibr.v1n2p140

Mohamed, M. M. (2010). Does efficiency matter? Examining the efficiency-profitability link in the US specialty retailer and food consumer stores. International Journal of Productivity and Performance Management, 59, 255-273. http://dx.doi.org/10.1108/17410401011023582

Salhieh, L. (2011). An exploratory study of the relationship between supply chain management practices and technical efficiency of Jordanian manufacturing companies. International Journal of Business and Management, 6(12), 126-134. http://dx.doi.org/10.5539/ijbm.v6n12p126

Thomas, R. R., Barr, R. S., Cron, W. L., \& Slocum, J. W. (1998). A process for evaluating retail store efficiency: A restricted DEA approach. International Journal of Research in Marketing, 15(5), 487-503. http://dx.doi.org/10.1016/S0167-8116(98)00021-4

\section{Note}

Note 1. The complete data set is available in CSMAR. It can also be obtained from us upon request. 


\section{Appendix}

Table A. Companies' full name and abbreviation

\begin{tabular}{clc}
\hline Number & Full Name & Abbreviation \\
\hline 1 & Nanjing Central Emporium (Group) Stocks Co.,Ltd. & NJCE \\
2 & Shanghai New World Co.,Ltd. & SHNW \\
3 & Nanjing Xinjiekou Department Store Co.,ltd. & NJXJ \\
4 & Fujian Dongbai (Group) Co.,Ltd. & FJDB \\
5 & Nanning Department Store Co.,Ltd. & NNDS \\
6 & Chongqing Department Store Co.,Ltd. & CQDS \\
7 & Lanzhou Minbai Shareholding(group) Co.,ltd. & LZMB \\
8 & Yinchuan Xinhua Commercial (group) Co.,ltd. & YCXH \\
9 & Beijing Wangfujing Department Store (Group) Co.,Ltd. & BJWF \\
10 & Harbin Churin Group Jointstock Co.,Ltd. & HBCR \\
11 & Yonghui Superstores Co.,Ltd. & YHSS \\
12 & Hefei Department Store Group Co.,Ltd. & HFDS \\
13 & Xi'an Minsheng Group Co.,ltd. & XAMS \\
14 & Zhongbai Holdings Group Co.,Ltd. & ZBHG \\
15 & Guangzhou Grandbuy Co.,Ltd. & GZGB \\
16 & Rainbow Department Store Co.,Ltd. & RBDS \\
17 & Shanghai Join Buy Co.,Ltd. & SHJB \\
\hline & & \\
\hline
\end{tabular}

\section{Copyrights}

Copyright for this article is retained by the author(s), with first publication rights granted to the journal.

This is an open-access article distributed under the terms and conditions of the Creative Commons Attribution license (http://creativecommons.org/licenses/by/3.0/). 